\title{
Common, Luxury, and Fake Commodities: Intangible Cultural Heritage Markets in China
}

\section{Christina Maags}

\section{(2) OpenEdition}

\section{Journals}

Electronic version

URL: https://journals.openedition.org/chinaperspectives/12184

DOI: 10.4000/chinaperspectives. 12184

ISSN: 1996-4617

\section{Publisher}

Centre d'étude français sur la Chine contemporaine

Printed version

Date of publication: 1 September 2021

Number of pages: 7-17

ISBN: $979-10-91019-40-8$

ISSN: 2070-3449

\section{Electronic reference}

Christina Maags, "Common, Luxury, and Fake Commodities: Intangible Cultural Heritage Markets in China", China Perspectives [Online], 2021/3 | 2021, Online since 01 September 2021, connection on 18 November 2022. URL: http://journals.openedition.org/chinaperspectives/12184 ; DOI: https://doi.org/ 10.4000/chinaperspectives. 12184 


\title{
Common, Luxury, and Fake Commodities: Intangible Cultural Heritage Markets in China
}

\author{
CHRISTINA MAAGS
}

\begin{abstract}
Can traditional cultural practices thrive if they are commercialised? Or should the state protect them from "the market"? This study investigates these questions by studying the marketisation of traditional handicrafts in the tourism sector of Nanjing municipality (Jiangsu Province, China). Building on Boltanski and Esquerre's (2020) work on the "enrichment economy," I find that stateled marketisation efforts have simultaneously raised and distorted the value of intangible cultural heritage (ICH) commodities in China. Many ICH inheritors are stuck in the middle: although they benefit from enhanced recognition and valorisation of ICH products, they face difficulties in competing with "fake" and luxury ICH commodities. ICH commodities are thus characterised by an "in-between" status - between the enriched and the mass economy.
\end{abstract}

KEYWORDS: China, intangible cultural heritage (ICH), commodities, markets, luxury, fake.

\section{Introduction}

Can traditional cultural practices thrive if they are commercialised? Or should the state protect them from "the market"? This debate has been at the heart of international and domestic governments worldwide. According to the UNESCO' "Convention for the Safeguarding of Intangible Cultural Heritage" in 2003 (UNESCO 2003, hereafter: ICH Convention), governments should facilitate legislation, research, and awareness-building campaigns as well as support local communities in protecting their intangible cultural heritage (ICH), such as traditional songs, dances, and handicrafts. The ICH Convention does not foresee a role of markets in ICH safeguarding; instead, as Bortolotto (2019) notes, marketisation ${ }^{2}$ seems to be a "taboo" term that the diplomats and researchers who designed the convention did not consider. However, as many cultural practitioners need to make a living from their ICH practice, some scholars (Cohen 1988; Bortolotto and Ubertazzi 2018; Luo 2020) argue that the market - under certain circumstances - can play a role in ICH safeguarding.

The debate around ICH safeguarding versus ICH promotion via the market is highly relevant to contemporary China, where Chinese culture and traditions - after decades of criticism and repression - have been "revived" (Chau 2005; Gao 2013). Since the ICH Convention was adopted in 2004 (UNESCO 2020a), many Chinese cultural practices have now been reframed as intangible cultural heritage (feiwuzhi wenhua yichan 非物質 文化遺產) (You 2020). Although traditional handicrafts have been sold at Chinese rural and urban markets from time immemorial, the emergence of ICH as a concept and governmental ICH safeguarding efforts have had an impact on how traditional handicrafts are sold, by whom, and where.
This study seeks to inquire into the effects of $\mathrm{ICH}$ marketisation in China by asking: (1) what impact have the Party-state's efforts to safeguard and promote ICH had on the sale and sellers of traditional handicrafts? (2) What implications do these efforts have for ICH safeguarding? This study investigates these questions by exploring the marketisation of traditional handicrafts in the tourism sector of Nanjing municipality (Jiangsu Province). Building on Boltanski and Esquerre's (2020) work on the "enrichment economy," the study examines the relationship between the state and the sellers in the "ICH market" as found in museums and heritage sites by combining an analysis of participant observation and interviews with an analysis of prices for $\mathrm{ICH}$ commodities.

I find that state-led marketisation efforts have simultaneously raised and distorted the value of ICH commodities in China. While the enhanced recognition and valorisation of $\mathrm{ICH}$ has benefited all sellers of $\mathrm{ICH}$ commodities, this benefit is unevenly spread among the sellers. Sellers of luxury and souvenir ICH commodities have gained most, since they can use the label either to justify high prices for luxury goods or market cheap machine-produced commodities as "ICH." Many traditional cultural practitioners (ICH inheritors) - who are the focus of the $\mathrm{ICH}$ Convention - are stuck "in-between." Although they benefit from enhanced recognition and valorisation of $\mathrm{ICH}$ products as well, they face difficulties

1. United Nations Educational, Scientific and Cultural Organisation.

2. Marketisation is commonly understood as "the integration of competition and price mechanisms into public services" (Bevir 2012) or sectors. For heritage, this means that heritage is decoupled from being a public sector good to being a commercial good subject to competition and pricing (Dicks 2003). 
in competing with other ICH sellers: either due to the cheap prices of tourist souvenir "knock-offs," or because it is hard to have a commodity recognised as a luxury item. While the former two commodities, luxury and souvenir goods, are common items for "collectors," products that are "in-between" are often not collected for two reasons: firstly, they are products of daily use for which cheaper mass-produced commodities exist; or secondly, they are associated with folklore and not "high culture" and thus are regarded as common (not luxury) goods.

This study's implications are that the market can in fact contribute to ICH safeguarding if traditional handicrafts are protected from unfair market competition. While the Party-state's embrace of the "enrichment economy" can enhance the value of traditional cultural practices by reframing them as $\mathrm{ICH}$, this only works if "authentic" representations of Chinese culture receive this enrichment and recognition via state logos or brands. With this state recognition, ICH commodities may move up the market segment, and be perceived as luxury goods or as something of "value." Without certified recognition, they will not be able to compete with mass-produced commodities and thus will remain in their "inbetween" state.

In the following, I will first introduce the reader to the debate over Chinese "ICH and the market" as well as Boltanski and Esquerre's (2020) work on the "enrichment economy" - the analytical framework of this study. Subsequent sections discuss the Party-state's efforts in $\mathrm{ICH}$ safeguarding and marketisation and their impact on $\mathrm{ICH}$ commodity sellers in Nanjing. A brief conclusion sums up the paper.

\section{China's ICH between the market and communities: A debate}

In the scholarly literature, the simultaneous safeguarding and commercialisation ${ }^{3}$ of $\mathrm{ICH}$ often appears to be an oxymoron. Many studies on ICH practices in China (Chen 2015; Massing 2018) have reported on the negative consequences of commercialisation as a form of ICH safeguarding, such as the loss of cultural ownership (Chen 2015) or over-commercialisation in the tourism industry (Sigley 2010). This is comparable to over-commercialised mass tourism at World Heritage Sites (WHS) (Caust and Vecco 2017). The state-led development of ICH practices for consumption and display has caused communities and individuals who should be the bearers and beneficiaries of $\mathrm{ICH}$ to be marginalised or disempowered (Liang 2013; Chen 2015; Zhang 2020). You (2020) even goes further and criticises governmental recognition of $\mathrm{ICH}$ as such. As she notes, the process of framing something as $\mathrm{ICH}$ changes its meaning and thereby may lead to the disempowerment of communities that lack the authority to recognise and manage local cultural practices (ibid.). The fact that $\mathrm{ICH}$ practices, which are deemed to be alive, dynamic, and communal, are "governed" by the state or managed by businesses for political and economic gain (Chen 2015; You 2020) is at the heart of this criticism.

Other scholars have demonstrated how the market can be a way to support ICH safeguarding. Studying food-related ICH, for instance, Bortolotto and Ubertazzi (2018) argue that while "commodification is regarded as a major risk of $\mathrm{ICH}$ promotion, the market often intersects with, and is necessary for, the perpetuation of food-related cultural practices" (2018: 412). Many Chinese scholars (Gong 2017; Cao and He 2018; Wang 2018) believe that ICH brands and products are necessary to enhance ICH tourism and cultural industries (Maags and Holbig 2016). Lin and $\mathrm{Ma}$ (2020), for instance, have argued that traditional handicrafts have always been subject to the rhythm of the market and cannot be protected as an entity separate from the market. Other Chinese scholars, such as Ding and Zheng (2015) or Li et al. (2019), argue that commercialisation of certain $\mathrm{ICH}$ practices is necessary to raise awareness and enable consumption of goods produced by ICH practitioners such as embroidery products for tourists (Cao and He 2018). In their view, only if there is an ICH commodity market will it be possible for the next generation to become interested in and earn a living from producing $\mathrm{ICH}$-related goods (Wang 2018).

The debate, however, is not clearly separated into pro and con marketisation camps, but includes many who discuss equally negative and positive consequences of $\mathrm{ICH}$ marketisation. While $\mathrm{CaO}$ and $\mathrm{He}$ (2018), for instance, argue for the need to enhance the sale of Qiang embroidery to support local tourism development and household income, they also acknowledge the need for government policy and financial support in dealing with the fierce competition between tourism regions and machine-produced "ICH commodities." Similarly, in studying ICH theme parks in China, Massing (2018) points out that ICH theme parks, for instance, can contribute to $\mathrm{ICH}$ safeguarding by increasing local pride in $\mathrm{ICH}$, while simultaneously doing little to transmit cultural knowledge to the next generation (Massing 2018). How ICH is marketised and with what effects (e.g. who benefits, and how) is thus a crucial question when trying to find an answer to how ICH marketisation can support ICH safeguarding.

Finally, ICH marketisation is related to the value of ICH. Is ICH to be safeguarded and promoted due to its intrinsic value to a community or humanity as a whole - as both the ICH and the World Heritage Convention contend? (UNESCO 1972, 2003) Or is there a case to be made for valorising it as a public or even commercial good? Many scholars (del Barrio et al. 2012; Francioni 2012) point to the fact that cultural heritage can have intrinsic, economic, cultural, and public value - all at the same time. While heritage may have intrinsic value to the community, it may also have public value to a nation as it fosters a national identity. Furthermore, heritage is often seen as being of economic value based on its commercial potential (Francioni 2012). In promoting heritage, the Chinese Party-state has therefore sought to simultaneously promote its intrinsic, public, and economic value (Maags 2018b).

Official recognition of cultural practices as "intangible heritage" legitimises these values and changes the inherent nature of $\mathrm{ICH}$ (Zhu and Maags 2020): while cultural practices have value to many communities and individuals, the sheer framing of something as $\mathrm{ICH}$, in other words, the creation of "heritage," is in itself an "instrument for adding value" (Kirshenblatt-Gimblett 1995: 374). Following this logic, as Kreps notes, the more authentic an $\mathrm{ICH}$-related good is perceived to be, the greater the increase in its market value (2012: 179). Yet authenticity is sometimes associated with being valorised mainly for its intrinsic value, and therefore "outside" the market. It is the tension between these different kinds of values ascribed to $\mathrm{ICH}$ that makes $\mathrm{ICH}$ simultaneously something that is in need of protection from the market as well as a resource for sale in the market.

3. Commercialisation refers to "the act of using something to try to make a profit, especially in a way that other people do not approve of." See "Commercialization," Oxford Learner's Dictionary, 2020, https://www.oxfordlearnersdictionaries.com/definition/english/commercialization (accessed on 28 August 2020). 


\section{ICH within the "enrichment economy"}

The above debate on the relationship of culture to the market is not only discussed in heritage studies but also in sociology, particularly the "sociology of value" literature. In their work Enrichment - A Critique of Commodities, Boltanski and Esquerre take a clear side in this debate, arguing that "the economy does not pervert culture; culture requires the economy. Without the economy there is no culture" (2020: 51). They find that the role of culture has very much increased in the global economy since postindustrial, advanced economies have outsourced industrial production to developing countries. In search of alternative ways to make profit, governments and businesses have turned to using the past as a resource for generating wealth, which the authors call "the enrichment economy."

According to Boltanski and Esquerre, "things" are "enriched" with value by adding narratives of their authenticity and distinctiveness. While industrial products are advertised based on their analytical characteristics (e.g. their size or material), things are "enriched" by bestowing them with a narrative of their history or creation. In addition, while the commercial potential of industrial goods decreases over time, the commercial potential of "enriched" things increases over time. This makes it possible for the consumer to collect enriched things as an asset. Enriched things are thus commonly not needed or used in practice. Yet not only "things" such as antiques or fine art are enriched, but also cultural activities such as performing arts or festivals, because they enable the consumption of the past (ibid.: 11-42). For instance, Boltanski and Esquerre explicitly mention ICH when discussing the ways in which French gastronomy is constructed as a part of French "non-material heritage" (ibid.: 17). ${ }^{4}$

For Boltanski and Esquerre, an enriched "thing" becomes a commodity when it is allocated a price. There is thus a difference between the value and the price of a commodity. While the former is inherent to the thing (ideal or fictional reality), the latter is used for transactional purposes in a circumstantial reality. The two are, however, connected as we justify the value of a thing by reference to a "meta price" - something is worth a certain amount of money - which might differ from the price. As we constantly compare prices with each other, this structure of relative prices helps us navigate the market as it provides us with the cognitive arrangements we need to navigate uncertainty. For instance, when navigating the market, we consider whether and how a commodity is presented or bestowed with a narrative - as this adds value - and whether its commercial potential will increase or decrease over time. Although political institutions are established to help navigate the market, they can also be manipulated, enabling false information and advertising. The market might also include a copy (of an original) or fake (including a false attribution or not "real") commodities (ibid.: 72-124).

While the enrichment of cultural "things" and activities has been used to generate profit in a postindustrial society, it has also increased social inequalities. Since it forges a divide between those who can afford to purchase "luxury" commodities and experiences, and those who cannot, it undermines the democratisation of culture, which seeks to reduce the difference between "popular culture" and "high culture." This creates two diverging consumption patterns in which the rich consume luxury and the rest consumes industrial, mass-produced goods (ibid.: 51-67). As we will see in the following, the phenomenon of the enrichment economy, as examined in France, helps us explain the role and value $\mathrm{ICH}$ has acquired in China today.

\section{ICH marketisation: Relations between the state, the market, and the sellers}

After the People's Republic of China's (PRC) ratification of the ICH Convention in 2004, the Party-state quickly created its own ICH regime. Starting with its 2005 landmark policy "Opinions of the General Office of the State Council on Strengthening the Protective Work of China's Intangible Cultural Heritage" (State Council 2005), the Partystate adopted many programmes for domestic documentation and ICH safeguarding. The most significant governmental programmes are based on creating two "ICH lists." Similar to the UNESCO's Representative List of the Intangible Cultural Heritage of Humanity (UNESCO 2020b), the Chinese government first compiles a domestic list of $\mathrm{ICH}$ practices - at the county, municipal, provincial, and national levels (Svensson and Maags 2018). This list is to raise awareness for ICH safeguarding and constitutes the basis for ICH safeguarding projects at different government levels (State Council 2005). The second list comprises "ICH inheritors" (cultural practitioners of a particular ICH practice). This list is created in conjunction with the first list of ICH practices in order to support bearers or practitioners of these $\mathrm{ICH}$ practices in transmitting their knowledge to the next generation. While the government provides them with a small annual stipend and in-kind support, ICH inheritors teach their practices and perform ICH practices at museums, schools, and public events (Ministry of Culture 2008; Maags 2019). The Chinese Party-state's early legislation, ICH lists, and inheritor programmes closely followed UNESCO recommendations and did not mention marketisation.

In recent years, however, China's ICH legislation and administration ${ }^{5}$ have increasingly shifted towards regarding $\mathrm{ICH}$ as a resource for economic development. This shift is noticeable in the Party-state's increased focus on developing the cultural industries (Keane 2013) and tourism (Yan and Bramwell 2008) since the mid-2000s, which has become gradually more explicit over the course of the last decade. According to Article 37 of 2011 China's ICH law, for instance:

The state encourages and supports the leveraging of the special advantages of intangible cultural heritage resources and the reasonable utilisation of the representative items of intangible cultural heritage to develop cultural products and cultural services with local and ethnical features and market potential on the basis of effective protection of those items (WIPO 2020).

China's ICH law thus encourages the use of ICH for developing cultural products and services, while stressing, however, that it should be used in a "reasonable" manner to support ICH safeguarding.

$\mathrm{ICH}$ marketisation is to be achieved by promoting $\mathrm{ICH}$ in the tourism industry, particularly in the form of traditional handicrafts. As policies from the Ministry of Culture show, the "market potential" of ICH practices is to be enhanced through, for instance, the joint development of cultural tourism and folk festivals as a form of "productive" protection (Ministry

4. This thought is in line with what Deacon (2019) calls "credence goods." Taking the example of traditional foods, she argues that it is "the way in which they are made, or their ingredients, [which] give them value" (2019: 522) as they are valorised due to their "credence attributes" or "seller's credentials" (ibid.).

5. The administrative shift towards linking culture and commerce was completed during the most recent administrative restructuring of 2018, when the Ministry of Culture was merged with the National Tourism Administration to form the Ministry of Culture and Tourism (State Council 2018). 
of Culture 2012; see also Massing 2018: 68). In particular, traditional handicrafts produced by companies and social organisations are to play a key role in driving this economic development (Ministry of Culture and Tourism 2018). In short, one strategy to support the marketisation of $\mathrm{ICH}$ is to promote companies, social organisations, and ICH inheritors in selling traditional handicrafts at tourism sites and folk festivals.

A key feature within this marketisation has been the use of the governmental "ICH logo" as a branding device for ICH products (Maags 2018a). Legally, the owner of this logo is the Ministry of Culture and Tourism, which can empower superordinate government agencies, danwei 單位 (work units), organisations, and individuals to use this logo. The Ministry encourages the use of this logo for public events (gongyi huodong 公益活動). Yet if it is used for commercial events (shangye huodong 商業活動), including selling or marketing ICH commodities, one has to first apply for ministerial approval. Any income generated by commercial use of the logo is to be used for ICH safeguarding (Ministry of Culture 2007).

The Chinese Party-state's support for marketising ICH in the tourism industry is a clear effort in developing its "enrichment economy." In line with Boltanski and Esquerre, this is done by promoting heritage sites and "local cultural singularities" (2020: 20) such as local handicrafts and food stuffs in the tourism industry (Demgenski 2020). The ICH safeguarding system with its lists and logo authenticates certain traditional practices as "ICH" and links them to the narrative of China's rich history, culture, and traditions. Consequently, traditional handicrafts, which declined in importance during the era of industrialisation, have the potential of gaining new meaning and value in the Chinese "enrichment economy." Whether the state-led ICH marketisation can support ICH safeguarding, however, can only be examined when looking into how ICH commodities are sold in the tourism industry, by whom, and with what implications.

\section{ICH commodity sellers in Nanjing's tourism market}

To examine the marketisation of ICH in the Chinese tourism industry, I have selected three case study locations in Nanjing, which is known for its historic production of handicrafts for the imperial court (Zhu and Maags 2020). The three locations include (1) the Jiangsu Provincial Museum and (2) the Ethnic Folklore Museum, both of which house an ICH exhibition; and (3) the tourist market surrounding the heritage site of Fuzi Temple. The three case study locations offer an insight into different types of sellers (museum shops, ICH inheritor-run stalls, and tourist souvenir vendors) at different locations associated with Nanjing's tourism industry: museums and heritage sites. At each location, I conducted participant observation, informal conversations, and semi-structured interviews ${ }^{6}$ with sellers, and collected prices ${ }^{7}$ of ICH commodities.

\section{Jiangsu Provincial Museum}

The Provincial Museum was made up of various majestic and modern buildings, one of which housed an "ICH exhibition" in the basement. Before entering this exhibition, the visitor passed by a small museum shop offering various $\mathrm{ICH}$ products. In the $\mathrm{ICH}$ exhibition itself, visitors were first introduced to the notion of ICH and a list of provincial-level $\mathrm{ICH}$ practices before moving into an open space of different "stalls" representing each a particular ICH practice found in Jiangsu Province. The stalls were arranged in a way so that the visitor passed by each stall while crossing the exhibition hall.

Speaking to the sellers, I noticed a seemingly clear hierarchy among the stalls in terms of the price and presentation of $\mathrm{ICH}$ commodities. On the face of it, most appeared to be provincial-level ICH inheritors. All sellers were there to sell ICH products and educate visitors on their $\mathrm{ICH}$ practice. Yet, while some sellers used the stall to simultaneously produce and sell their products, others were ICH inheritors' students or regular shop assistants. The latter two groups represented the ICH inheritor who was otherwise involved - often in a shop elsewhere.

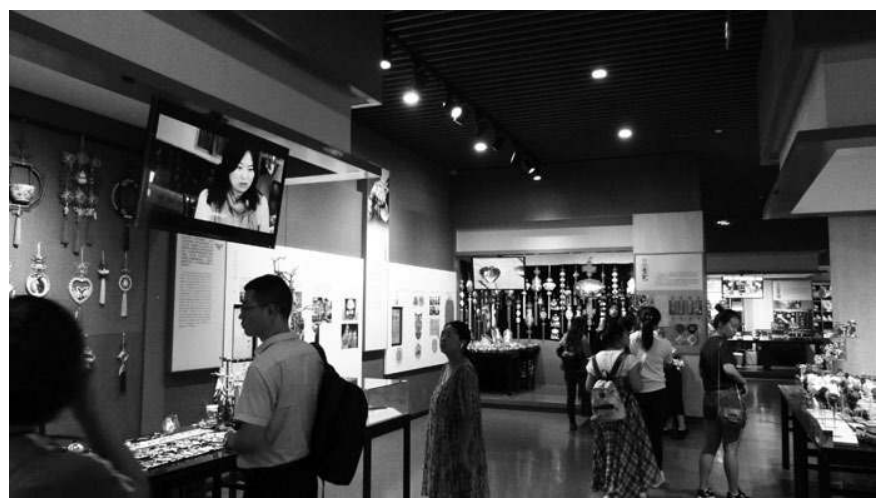

Figure 1. Stalls at the Jiangsu Provincial Museum. Credit: author.

The hierarchies among ICH inheritor stalls were also mirrored in the prices of their ICH commodities. Many of the stalls offered ICH goods in a lower price range (below $100 \mathrm{RMB}$ ). Most of these commodities were goods for daily use, such as bracelets (20-40 RMB), dough figurines (miansu 面塑) (15-30 RMB), paint brushes (25-50 RMB), and paper lanterns (25-40 RMB), depending on the shape and size of the commodity. None of these ICH inheritors had a shop outside the museum. As the paper lantern maker explained, she was dependent on selling her lanterns at the museum to make a living. Although she had tried to sell her handmade lanterns online, she found it hard to compete with the mass-produced lanterns, as it was more difficult to prove that her lanterns were handmade. In other words, she found it harder to prove to customers online that her "authenticity" and "distinctiveness" would justify the higher price (and thus value) in comparison to machine-produced commodities.

Other ICH inheritors offered commodities that were in a low-tomedium price range (up to several hundred RMB) (see Table 1). A fan maker, for instance, offered machine-made fans between 20 and 70 RMB and handmade fans starting at 300 RMB. Similarly, the shadow puppet shop clerk sold little bookmarks for 20 RMB, but had a selection of framed shadow puppets that started at $75 \mathrm{RMB}$ and went up to several hundred RMB.

Finally, the ICH exhibition offered "luxury" ICH products. One example was an olive pip carver who sold key chains for around 3,000 RMB, and a furniture maker who - while displaying some furniture pieces - sold

6. Materials were collected during multiple field visits from 2014 to 2019. Nine formal semistructured interviews were conducted with ICH inheritors to gain insight into sellers' perspectives on selling $\mathrm{ICH}$ products and the impact of government policy on the ICH market.

7. I collected prices of $\mathrm{ICH}$ goods in order to compare these within and across different locations. Including an analysis of prices in the study has two advantages. First, in addition to sellers' comments regarding the intrinsic value of ICH products, I can assess the monetary "value" of ICH products at each site. Second, I obtain insights into the different market segments at each location to differentiate and group together sellers according to seller type, $\mathrm{ICH}$ good, and product price. Price levels reflect prices of summer 2019. 
wooden and pearl jewellery ranging from 80 RMB to 600 RMB. As in the case of the fan maker, the olive pip carver and the furniture maker in fact ran enterprises elsewhere in addition to this smaller stall in the museum. Many of the products above were not for daily use, but for display and collection.

When leaving the $\mathrm{ICH}$ exhibition, the visitor entered an open courtyard where a private luxury shop and a museum shop were located. While the private shop sold statues and vases decorated with golden foil (Nanjing jinbo 南京金箔) starting at several hundred RMB, the museum shop offered various ICH commodities such as paper cuts (40-180 RMB), dough figurines (starting at $40 \mathrm{RMB}$ ), jewellery boxes (starting at 280 $\mathrm{RMB}$ ), hand-carved red lacquer boxes (starting at $420 \mathrm{RMB})$, wooden combs (520 RMB), and metal cups (starting at 240 RMB). In contrast to most goods sold in the $\mathrm{ICH}$ exhibition, commodities here were more expensive and could be considered luxury items. Moreover, there was a clear differentiation between $\mathrm{ICH}$ inheritors who produced and sold at the exhibition for a living, and those who just regarded the stall as a form of advertising for commodities they sold elsewhere. Yet, to make a profit, sellers brought along cheaper commodities, some of which were machine-produced, to sell as souvenirs to less affluent museum visitors.

Table 1. Examples of ICH commodities and prices at the Jiangsu Provincial Museum

\begin{tabular}{|l|l|l|l|}
\hline Commodity type & $\begin{array}{l}\text { Price } \\
\text { low price } \\
\text { range }\end{array}$ & $\begin{array}{l}\text { medium price } \\
\text { range }\end{array}$ & $\begin{array}{l}\text { high price } \\
\text { range }\end{array}$ \\
\hline $\begin{array}{l}\text { ICH exhibition stalls } \\
\text { Dough figurines }\end{array}$ & $15-30$ RMB & & \\
\hline Paper lanterns & $10-40$ RMB & & \\
\hline Bracelets (thread) & $20-40$ RMB & & \\
\hline Paint brushes & $25-50$ RMB & & \\
\hline Fans & $20-70$ RMB & $200-300$ RMB & \\
\hline Shadow puppets & \multicolumn{3}{|l|}{} \\
\hline $\begin{array}{l}\text { Jewellery } \\
\text { (furniture maker) }\end{array}$ & & $75-350$ RMB & \\
\hline $\begin{array}{l}\text { Olive pip carving } \\
\text { ICH museum shop }\end{array}$ & $40-600$ RMB & \\
\hline Paper cuts & $40-100$ RMB & $100-180$ RMB & \\
\hline Dough figurines & 40 RMB \& up & & \\
\hline Clay figurines & $30-40$ RMB & 80 RMB & \\
\hline Jewellery boxes & & 240 RMB \& up & \\
\hline Red boxes & & 420 RMB \& up & \\
\hline Wooden combs & & 520 RMB \& up & \\
\hline Metal cups & & 240 RMB \& up & \\
\hline Opera figures & & $100-350$ RMB & \\
\hline
\end{tabular}

Source: author.

\section{Ethnic Folklore Museum}

In comparison to the Jiangsu Provincial Museum, the Ethnic Folklore Museum was housed in a former residence built during the Qing Dynasty, the Residence of Gan Xi, which was made up of various traditional courtyards, gardens, and houses. Although very spacious in size, the

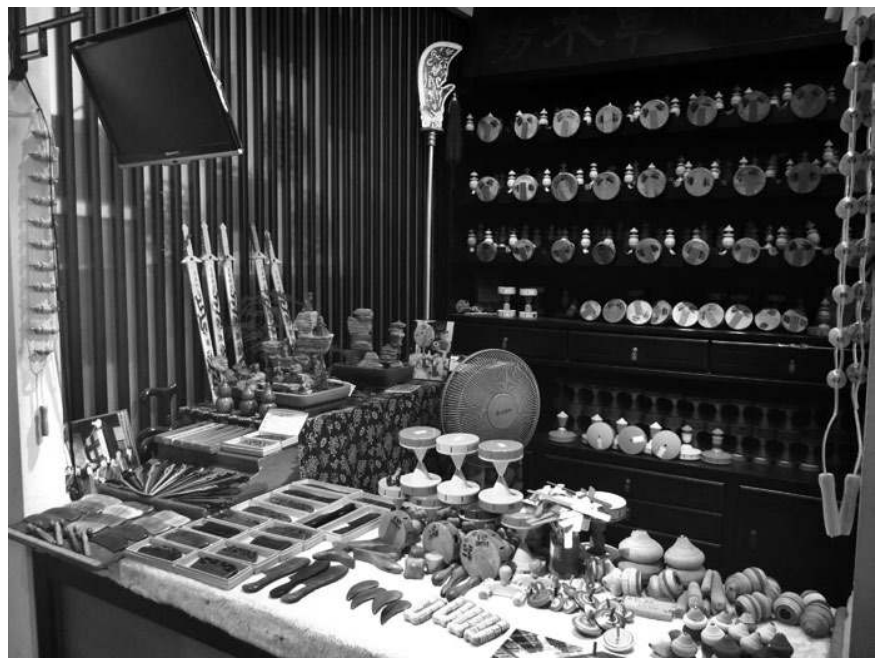

Figure 2. Typical stall at the Ethnic Folklore Museum. Credit: author.

museum's entrance was tucked away in a set of alleyways. Visitors first walked past newly built, traditional-looking buildings in which restaurants and shops offered their goods. Once they entered the Gan Residence, they could explore different houses and rooms, many of which had been offered to ICH inheritors as workshop spaces. While all ICH inheritor workshops presented traditional handicrafts, the museum offered one bigger hall as a rehearsal space for traditional Chinese music troupes.

The Ethnic Folklore Museum was similar to the Provincial Museum in that all sellers were ICH inheritors, thereby creating a similar market environment to the Provincial Museum's ICH exhibition. However, as there was no museum shop within the museum, and so far, none of the shops in the alleyways outside the museum offered any ICH-related commodities, the market environment differed significantly from that of the Provincial Museum. ICH inheritors were more "protected" from competing with businesses selling non-handmade goods.

In contrast to the Provincial Museum, most ICH commodities sold at the Ethnic Folklore Museum were within the low or medium price range (10-300 RMB). For instance, a traditional wooden toy maker offered a bamboo-copter for 10 RMB and spinning tops for 20-30 RMB (see Table 2), whereas the wood carver had bookmarks for 20-30 RMB and small figures for 20 RMB on display. Similar to the fan maker at the Provincial Museum, many of these sellers displayed a greater product variety at the back of their shops. While the toy maker also offered a range of Chinese yo-yos (also known as diabolos) starting at 80 RMB, the wood carver offered wooden statues of Buddhas, historical figures, and even personalised busts, starting at 200 RMB depending on the wood. As she explained, such busts were especially popular with foreign tourists who cherished the traditional wood carving technique but preferred an image that had personal relevance over those with religious or historical connotations. Only a few sellers sold high-priced goods, such as the clay figurine seller who offered intricate figurines for 3,000 to 5,000 RMB.

Many of the other $\mathrm{ICH}$ inheritors also sold $\mathrm{ICH}$ commodities in a medium price range, yet as they lacked cheaper variants of their handicraft, they complemented their merchandise with other $\mathrm{ICH}$ commodities. The traditional painter, for instance, sold bracelets with an inscribed rice kernel (35 RMB) and wooden combs (65 RMB) to enhance sales. In fact, his sister (who was the ICH inheritor that was offered the workshop space) made the paintings, he made the rice kernel bracelets, and 
the other $\mathrm{ICH}$ commodities were brought in from elsewhere. As few visitors were interested in the more expensive paintings, he and his sister agreed they would jointly use the space and offer more goods to make a greater profit. Many used this strategy. The traditional toy maker, while specialising in Chinese yo-yos, also sold wooden combs and hair needles. The wood carver, the toy maker, and the painter were therefore in competition over selling wooden combs although none of them was a traditional Changzhou "comb" ICH inheritor.

Table 2. Examples of ICH commodities and prices at the Ethnic Folklore Museum

\begin{tabular}{|l|l|l|l|}
\hline Commodity type & $\begin{array}{l}\text { Price } \\
\text { low price } \\
\text { range }\end{array}$ & $\begin{array}{l}\text { medium price } \\
\text { range }\end{array}$ & $\begin{array}{l}\text { high price } \\
\text { range }\end{array}$ \\
\hline Paper cuts & $38-65$ RMB & $500-600$ RMB & \\
\hline Bamboo copter & 10 RMB & & \\
\hline Spinning tops & $20-30$ RMB & & \\
\hline Bookmarks & $20-30$ RMB & & \\
\hline Small figurines & 20 RMB & & $3000-5000$ \\
\hline Clay figurines & $15-35$ RMB & $65-80$ RMB \\
\hline Chinese yo-yos & 80 RMB & & \\
\hline Hair needles & 50 RMB & & \\
\hline Wooden combs & 65 RMB & & \\
\hline Wooden statues & & 200 RMB \& up & \\
\hline Personalised busts & & $65-280$ RMB & \\
\hline Paintings & & $160-360$ RMB & \\
\hline Cloth paintings & & 200 RMB \& up & \\
\hline $\begin{array}{l}\text { Wedding } \\
\text { ornaments }\end{array}$ & & & \\
\hline
\end{tabular}

Source: author.

A price comparison between the Provincial Museum and the Ethnic Folklore Museum showed that many items had a comparable or slightly cheaper price at the Ethnic Folklore Museum. ${ }^{8}$ The paper cutter at the Ethnic Folklore Museum, for instance, sold small paper cuts for 38 RMB and medium-sized paper cuts for 65 RMB. The museum shop, in contrast, priced the same smaller paper cuts at 40 RMB and medium-sized cuts at 160 RMB. Similarly, whereas $3 \mathrm{~cm}$ clay figurines were sold for 35 RMB at the Ethnic Folklore Museum, at the museum shop clay figurines of the same size were priced at 30 to 40 RMB. There thus seemed to be an agreement over the "meta price" (value) of different kinds of traditional handicrafts. Nevertheless, there were also vast differences in ICH commodities. Certain wooden combs at the museum shop, for instance, were 520 RMB, while most of the combs sold at the Ethnic Folklore Museum were 50 to 65 RMB. For the ordinary visitor, it was hard to identify (and thus justify) why one $\mathrm{ICH}$ commodity was priced at one level, while the other seemingly similar commodity was priced differently, if there was no contextual information at hand. ICH inheritors often provided this information by speaking about the material and craft techniques.

\section{Heritage site: Fuzi Temple}

Finally, the tourist market around Fuzi Temple again offered a different market environment. On the one hand, the great majority of shops were operated by souvenir shop owners who offered various commodities, many of which were machine-produced versions of local $\mathrm{ICH}$ commodities. On the other hand, ICH inheritors were provided with around ten small workshops in a designated corner in the area. Both seller types were thus located in the same area. They were, however, still clearly separated, as the ten ICH inheritor workshops were tucked away in a quiet and less visible backyard. For this reason, a clear difference between the spaces was that while the tourist areas were bustling with customers, the zone with $\mathrm{ICH}$ inheritor workshops was rather lifeless. One ICH inheritor located there was in fact the wood carver, who ran a shop at the Ethnic Folklore Museum during the day and then rushed to Fuzi Temple at night due to the many tourists. As she explained, many ICH inheritors who were given a shop space there chose not to open it for business and instead used it as storage or workshop space. This was because the area was difficult for tourists to find, and the sellers could not compete with the machine-produced "ICH commodities" sold by souvenir shops.

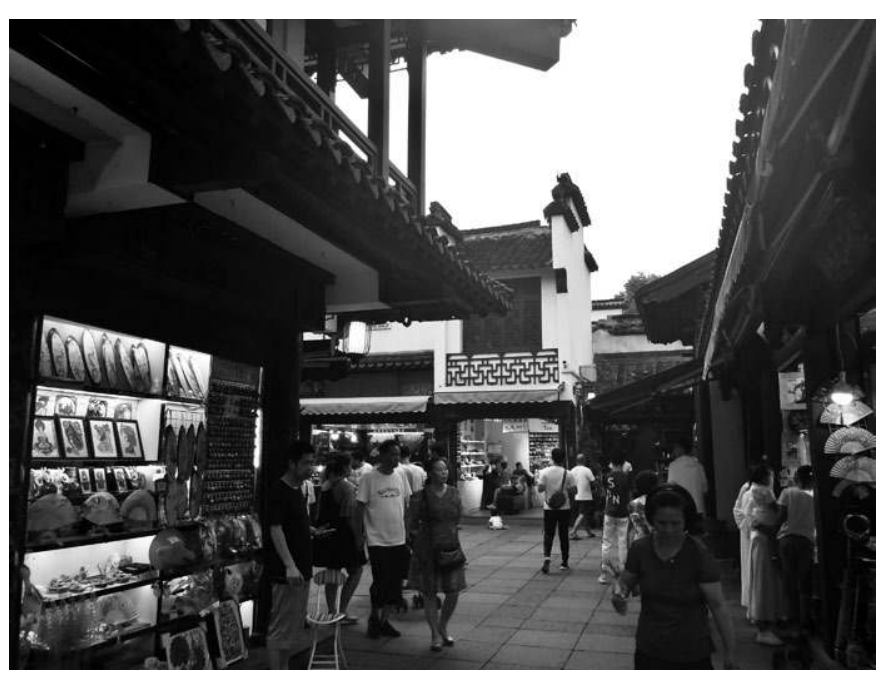

Figure 3. Tourist shops at Fuzi Temple. Credit: author.

Tourists walking through the shops noticed a striking price difference between the handmade and machine-produced "ICH commodities." Whereas small traditional paper cuts were sold for around 40 RMB at both museums, they were sold for 20 RMB in the tourist area. When asked whether they were handmade, the souvenir vendor argued that they were, and justified this by showing me the $\mathrm{ICH}$ logo on the packaging, which was to enrich the commodity's value. Similarly, supposedly hand-carved combs were sold for a third or half the price of the ones at the museums (15 to $30 \mathrm{RMB}$ ). Other ICH commodities with similar price differences included framed shadow puppets (20 RMB at the tourist shop; 70 RMB at the Provincial Museum) and wooden hair needles (28 RMB at the tourist shop; 50 RMB at the Ethnic Folklore Museum). Due to the large price difference, it was clear that the surrounding tourist shops undercut the ICH inheritors' prices.

However, not all alleged "ICH commodities" were sold at very low prices, but were comparable to the ones found in the Provincial and Ethnic Folklore Museums. Tourists at Fuzi Temple could also find similarly priced traditional paint brushes, clay figurines, wooden combs, and paper cuts. Some of these tourist shops included small workshop spaces where

8. This difference might be due to the Provincial Museum taking a small commission for selling ICH inheritor commodities 
rice kernels or stones were engraved using an electric engraver. Others seemed to specialise in certain products, suggesting that these sellers might in fact be selling handmade products that could be categorised as "ICH."

The main challenge for the visitor was to navigate the commodities and prices. Most sellers claimed to sell handmade commodities, and many used the ICH logo or just a sign saying "ICH" to claim authenticity of their products (see Figure 4). Judging from the prices and the fact that it was unlikely that they were handmade at such a low price, it was clear that many "ICH commodities" were machine-produced - such as the allegedly "hand-embroiled silk paintings" for 35 RMB. However, some commodities might in fact have been handmade but happened to be sold in a souvenir shop. For the untrained eye, it was hard to differentiate between the two, as they were sold side-by-side and were similarly advertised as Chinese or local "intangible cultural heritage."

Table 3. Examples of ICH commodities and prices at Fuzi Temple Commodity Type

\begin{tabular}{|c|c|c|c|}
\hline Commodity type & $\begin{array}{l}\text { Price } \\
\text { low price } \\
\text { range }\end{array}$ & $\begin{array}{l}\text { medium price } \\
\text { range }\end{array}$ & $\begin{array}{l}\text { high price } \\
\text { range }\end{array}$ \\
\hline \multicolumn{4}{|c|}{ Fuzi Temple inheritor stalls } \\
\hline Paper cuts & $40-80$ RMB & 180-900 RMB & \\
\hline \multicolumn{4}{|c|}{ Fuzi Temple tourist shops } \\
\hline Clay figures & $\begin{array}{l}3 \text { for } 20 \text { RMB, } \\
35-80 \text { RMB }\end{array}$ & & \\
\hline Paper cuts & $20 \mathrm{RMB}$ & & \\
\hline Shadow puppets & $15-45$ RMB & & \\
\hline Hair needles & $28 \mathrm{RMB}$ & & \\
\hline $\begin{array}{l}\text { Paintings in } \\
\text { small bottles }\end{array}$ & $28 \mathrm{RMB}$ & $\begin{array}{l}\text { elsewhere: } \\
\text { 160-240 RMB }\end{array}$ & \\
\hline Wooden combs & $15-30 \mathrm{RMB}$ & & \\
\hline Porcelain balls & $30 \mathrm{RMB}$ & & \\
\hline Silk paintings & $35 \mathrm{RMB}$ & & \\
\hline Fans & $10-25 \mathrm{RMB}$ & 45-85 RMB & \\
\hline Clay cups & $28-90$ RMB & & \\
\hline Snuff bottles & & $160-240$ RMB & \\
\hline
\end{tabular}

Source: author.

\section{Social implications of state-supported ICH marketisation}

Comparing the sellers at the three case study locations demonstrates that the "ICH market" is made up of various seller types, all offering different kinds of $\mathrm{ICH}$ commodities at varying prices. Some ICH sellers clearly sell luxury $\mathrm{ICH}$ commodities: the price is very high and the type of ICH commodity is very exquisite - commonly not a product for daily use. They are found in "high culture" cultural institutions such as provincial museums and operate one or several shops outside of the museum. In contrast, tourist vendors sell souvenir commodities, in part by decorating them with the official $\mathrm{ICH}$ or World Heritage Site logo. These commodities have a low price and are commonly found at popular tourist sites. In addition, many of these tourist vendors sell a wide range of ICH commodities at varying prices, making it difficult to discern which of the products, if any, are in fact "real" ICH commodities. Finally, most ICH inheritors' commodities appear to be in the middle of this hierarchy, especially those producing commodities for daily use. These sellers' prices are often two to three times higher than those of mass-produced souvenir commodities, but are handmade. There are thus clear hierarchies in terms of commodity type, price, and location within the $\mathrm{ICH}$ market.

Building on Boltanski and Esquerre's (2020) work on the "enrichment economy," these hierarchies are easily explained: some ICH inheritors - or traditional cultural practitioners in general - benefit from the "enrichment" that ICH commodities have experienced because these are now considered a "luxury" item. Luxury items, such as vases decorated with golden foil, silk-embroiled fans, and paintings, are luxury items not only due to the high prices at which they are sold, but also due to their image as symbols of "identity" and "difference." Once purchased, they can be displayed in homes and galleries, similar to pieces of art, as they are bestowed with a narrative of historical legacy dating back to the imperial eras. Commodities such as these have always been produced for the rich and noble. Yet with rising economic development and income levels in today's China, the emerging middle and upper classes (Li and Niu 2003) once again seek to purchase and collect such items because they demonstrate (social) difference and embody Chinese regional and national identities.

Many handmade ICH commodities, however, are not considered luxury items. They cannot be considered an asset to the customer. Based on the above analysis, this appears to be mostly the case for $\mathrm{ICH}$ commodities used on a daily basis such as paper lanterns, simple fans, or paint brushes. Many of these items are commonly associated with "folklore" - traditional practices found in the countryside - so they are not associated with "high culture" and thus social distinction. Many visitors still value such ICH commodities as they symbolise Chinese identity and culture, which enables $\mathrm{ICH}$ inheritors to still make a living from their sale. Yet, they cannot profit from the enrichment economy as much as "luxury" ICH sellers.

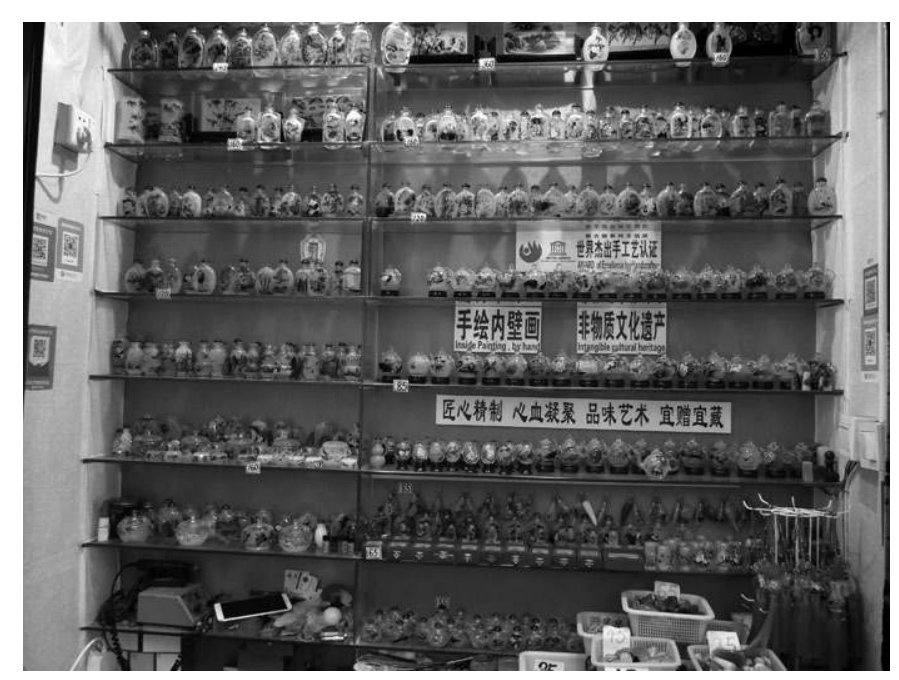

Figure 4. Stall selling "fake" ICH commodities at Fuzi Temple. Credit: author.

In fact, many ICH inheritors compete more directly with souvenir sellers than with luxury sellers because their customer bases overlap with tourist vendors selling mass-produced commodities. Museum and 
tourist site visitors who cannot afford luxury $\mathrm{ICH}$ commodities and wish to purchase a souvenir will likely choose between these two types of products. However, the machine-produced commodities are cheaper, more prominent in tourist locations, and falsely advertised as $\mathrm{ICH}$ commodities, at times with the help of ICH and WHS logos. It is this "false attribution" that makes them a "fake" ICH commodity and creates unfair market competition, as this falsely adds value to a supposedly handmade commodity. Consequently, visitors will find it difficult to navigate an $\mathrm{ICH}$ market at which handmade and machine-made ICH commodities are sold side-by-side and marketed in the same way (Deacon 2019). In other words, the structure of relative prices, which aims to help us navigate the market and thus uncertainty, is distorted because the commodities appear to be in the same "category" (of ICH commodities) and thus need to be compared based on their price. However, in fact, the commodities are not in the same category as one is machine-produced and the other can claim added value due to its intrinsic value of being $\mathrm{ICH}$.

Comparable to the imitations of luxury handbags and watches (Walley and Li 2013), the sale of "fake" luxury ICH commodities is less of a direct competition to "real" luxury ICH commodities as it is easier to identify these imitations. The mass-produced ICH commodities of daily use are only, for example, half the price of a "real" ICH commodity - and thus comparable. However, the "fake" ICH luxury items are around a tenth of the price of "real" ICH commodities - and thus the price appears much more out of proportion. For instance, while a machine-produced "handembroiled silk painting" is 35 RMB, a handmade one is easily 3,500 RMB or more. Many ICH commodities are thus suffering from their "in-between" status: they are not as cheap as common souvenirs but do not have the "aura" of a luxury ICH commodity.

A seemingly "easy solution" for this unfair market competition would be to enforce government legislation. For instance, based on government regulations (Ministry of Culture 2007), sellers need to register before using the state's ICH logo. Since ICH inheritor lists and programmes are administered by the Ministry of Culture and Tourism, it would be easy for ICH inheritors to register. Tourist souvenir sellers could be denied the use of the logo and prosecuted for illegal use. This would more explicitly signpost the "authenticity" of ICH commodities and enable tourists and other types of customers to navigate the market more easily. Moreover, it would allow "real" ICH commodities to move into a higher market segment. Yet, as Wang noted (2019), the Ministry of Culture and Tourism does not have the resources to check and prosecute illegal use of the $\mathrm{ICH}$ logo. In other words, unfair market competition arises because political institutions are not supervising the use of trademarks. On the other hand, not all cultural practitioners are recognised by the state as "ICH inheritors" (Maags 2019). Only granting official ICH inheritors the opportunity to use the logo would therefore further disadvantage "nonrecognised" traditional handcrafters in the market.

Another way to signpost "real" ICH commodities would be for governments to allocate different ICH sellers to different spaces. In the Provincial Museum and the Ethnic Folk Museum, ICH inheritors are provided with a clearly demarcated space that is easily differentiated from museum shops and commercial vendors. While this is also the case for Fuzi Temple, the space designated to $\mathrm{ICH}$ inheritors is not easy to find. If the local government were to offer ICH inheritors and other "nonrecognised" traditional cultural practitioners a prime location designated for handmade ICH commodities only, and signpost it as such, this would make it easier for tourists to navigate the space and thus the market. Yet, as one $\mathrm{ICH}$ inheritor noted, ${ }^{9}$ governments are less interested in the false advertisement of $\mathrm{ICH}$ commodities than in the economic development that the sale of $\mathrm{ICH}$ commodities generates. It would thus require strong government initiative to protect ICH inheritors from unfair market competition and help tourists understand the market environment.

Ultimately, state-supported marketisation has had ambiguous effects: on the one hand, it has created new opportunities for $\mathrm{ICH}$ inheritors and "regular" cultural practitioners to sell their ICH commodities in the tourism industry. Visitors are educated in $\mathrm{ICH}$ practices at museum exhibitions and by $\mathrm{ICH}$ inheritors showcasing their craft in workshop spaces. This raises public awareness regarding $\mathrm{ICH}$ safeguarding and enhances the value and recognition of traditional handicrafts. On the other hand, however, while the value of all ICH commodities seems to have increased overall, this has incentivised sellers who operate in the mass industry to take advantage of these business opportunities as well. Consequently, the value of $\mathrm{ICH}$ commodities is distorted by the simultaneous existence of machine-produced and handmade "ICH commodities," which directly counteracts governmental ICH safeguarding efforts. As the Party-state has allegedly spent 1 billion USD on ICH safeguarding since 2011, ${ }^{10}$ differentiating the "enrichment economy" including all ICH commodities - from the mass industry would thus not only support $\mathrm{ICH}$ safeguarding, but also make state investment more productive.

\section{Conclusion}

The Party-state's efforts to safeguard and marketise ICH commodities have simultaneously raised and distorted the value of $\mathrm{ICH}$ commodities in China. Whereas the overall increase in the intrinsic and monetary value of $\mathrm{ICH}$ commodities supports $\mathrm{ICH}$ safeguarding, the benefits of this valorisation are unevenly distributed. Luxury and tourist souvenir vendors benefit economically at opposing ends of the market segment as they cater to two different consumption patterns - luxury commodities found in the "enrichment economy," and mass-produced commodities in the mass economy. Both enable the tourist to "collect" a piece of China's past at different prices. Many traditional handicrafts, however, have an "inbetween" status: their commodities are neither a luxury item (as they are produced for daily use and are of folklore origin), nor as affordable as cheap tourist souvenirs.

This study has demonstrated ways to solve the dilemma between $\mathrm{ICH}$ and the markets. $\mathrm{ICH}$ marketisation can, in fact, contribute to $\mathrm{ICH}$ safeguarding if traditional handicrafts are protected from unfair market competition. The government thus needs to ensure that "culture" is significantly protected from "the market" where malpractices such as false advertising or fraud exist. In addition, governments at different levels need to support tourists in navigating the ICH market. The Partystate could, for instance, do so by enforcing existing policies on the $\mathrm{ICH}$ logo. It can also support ICH safeguarding by supporting ICH inheritors to sell their commodities in $\mathrm{ICH}$ exhibitions and designated areas for handmade products. This mirrors Yu et al.'s (2020) argument that ICH handicrafts should be considered "luxury" commodities. This would

9. Interview with an ICH inheritor from Nanjing, 22 March 2015.

10. "China Invests Heavily in Protection of Intangible Cultural Heritage," Xinhua, 18 October 2019, http://english.www.gov.cn/statecouncil/ministries/201910/18/content_ WS5da978bcc6d0bcf8c4c15626.html (accessed on 13 May 2021). 
raise their "in-between" status, moving closer to the high-end market segment. However, if the fruits of $\mathrm{ICH}$ marketisation are valued more than $\mathrm{ICH}$ safeguarding, governments are likely to turn a blind eye to unfair market competition, thereby undermining $\mathrm{ICH}$ safeguarding. Moreover, if only sellers recognised as "ICH inheritors" can use the ICH logo, this discriminates against and further alienates "non-recognised" handcrafters.

This study has demonstrated that the working mechanisms of the "enrichment economy" are not only found in advanced, postindustrial nations of "the West," but also in emerging economies such as China. Chinese society and economy are developing rapidly, which is evidently showed by the growing middle and upper classes (Li and Niu 2003). Chinese people are not only enjoying cultural experiences and commodities in "Western" enrichment economies, for example in the form of cultural tourism (Boltanski and Esquerre 2020: 25), but are similarly eager to experience and collect "enriched" commodities and activities in their own country. This is visible in the many Chinese collectors of Chinese antiques or contemporary art (Lincot and Black 2004; Devlin 2012) - two key industries within the "enrichment economy." The purchase of ICH commodities thus appears to be linked to processes of modernisation and class differentiation in China.

Boltanski and Esquerre's (2020: 39-41) bifurcation of economies into an "enriched economy" for the rich and a "mass economy" for the rest seems to be much more complex in practice. While certain consumption patterns are clearly bifurcated along the lines of luxury and mass production, there are also commodities and activities that lie somewhere in between, such as the $\mathrm{ICH}$ commodities for daily use. More research thus needs to be done on how the emerging "enrichment economy" can be conceptually refined and extended - something that Boltanski and Esquerre have acknowledged and encouraged themselves (ibid.: 7).

Nevertheless, as this study has shown, the increasing expansion of the enrichment economy can become an opportunity for supporting $\mathrm{ICH}$ safeguarding across different development contexts if "the rules of the game" are clear and enforced. Although UNESCO and many researchers reject using the notion of "authenticity" when referring to ICH (Bortolotto 2013; Deacon and Smeets 2013), clarifying and signposting the "difference" of ICH - in whatever way - is what enables it to be "enriched" and valorised. It is this enhanced value that supports both its safeguarding and marketisation. Future research therefore needs to extend our understanding of how the intrinsic and monetary value of $\mathrm{ICH}$ can be used to its benefit, not its detriment.

I Christina Maags is Lecturer in Chinese studies at the School of East Asian Studies, University of Sheffield. Her research focuses on the politics/political economy of cultural heritage in the PRC. She has studied, for instance, China's Living Human Treasures System and ICH marketisation and tourism. In a new research project, she examines the political economy of elder care in China. University of Sheffield, Jessop West, 1 Upper Hanover Street, S3 7RA Sheffield, United Kingdom (c.maags@sheffield.ac.uk).

Manuscript submitted on 27 October 2021. Accepted on 16 August 2021.

\section{References}

BEVIR, Mark. 2012. Key Concepts in Governance. Thousand Oaks: Sage. BOLTANSKI, Luc, and Arnaud ESQUERRE. 2020. Enrichment: A Critique of Commodities. Cambridge: Polity.

BORTOLOTTO, Chiara. 2013. "Authenticity: A Non-criterion for Inscription on the Lists of UNESCO's Intangible Cultural Heritage Convention." Paper presented at 2013 IRCI Meeting on ICH, UNESCO; Tokyo, 10-11 January 2013.

2019. "The Embarrassment of Heritage Alienability." Paper presented at International Cultural Heritage: Reconceptualization, Uses and Marketization, International Workshop at Zhejiang University; Zhejiang, 18-19 May 2019.

BORTOLOTTO, Chiara, and Benedetta UBERTAZZI. 2018. "Editorial: Foodways as Intangible Cultural Heritage." International Journal of Cultural Property 25: 409-18.

CAO, Xinghua, and Xiaoqing HE. 2018. "Study on the Development and Promotion of Intangible Cultural Heritage Tourism Commodities." International Core Journal of Engineering 4(12): 210-5.

CAUST, Josephine, and Marilena VECCO. 2017. "Is UNESCO World Heritage Recognition a Blessing or Burden? Evidence from Developing Asian Countries." Journal of Cultural Heritage 27: 1-9.
CHAU, Adam Yuet. 2005. "The Politics of Legitimation and the Revival of Popular Religion in Shaanbei, North-central China." Modern China 31(2): 236-78.

CHEN, Zhiqin. 2015. "For Whom to Conserve Intangible Cultural Heritage. The Dislocated Agency of Folk Belief Practitioners and the Reproduction of Local Culture." Asian Ethnology 74(2): 307-34.

COHEN, Erik. 1988. "Authenticity and Commoditization in Tourism." Annals of Tourism Research 3: 371-86.

DEACON, Harriet. 2019. "Safeguarding the Art of Pizza Making: Parallel Use of the Traditional Specialities Guaranteed Scheme and the UNESCO Intangible Heritage Convention." International Journal of Cultural Property 25: 515-42.

DEACON, Harriet, and Rieks SMEETS. 2013. "Authenticity, Value and Community Involvement in Heritage Management under the World Heritage and Intangible Heritage Conventions." Heritage \& Society 6(2): 129-43.

DEL BARRIO, María José, María DEVESA, and Luis César HERRERO. 2012. "Evaluating Intangible Cultural Heritage: The Case of Cultural Festivals." City, Culture and Society 3: 235-44.

DEMGENSKI, Philipp. 2020. "Culinary Tensions: Chinese Cuisine's Rocky Road toward International Intangible Cultural Heritage Status." Asian Ethnology 79(1): 115-35. 
DEVLIN, Johanna. 2012. "Repatriation via the Art Market: A New Type of Recovery, New Trends Coming from China." Journal of Art Crime 8: $45-55$.

DICKS, Bella. 2003. "Heritage, Governance and Marketization: A Casestudy from Wales." Museum and Society 1(1): 30-44.

DING, Yanni 丁燕妮, and ZHENG Yaoxing 鄭耀星. 2015. “非物質 文化遺產活態保護與旅遊利用研究: 以泉州德化瓷燒制技藝為 例" (Feiwuzhi wenhua yichan huotai baohu yu lüyou liyong yanjiu: yi Quanzhou Dehua ci shaozhi jiyi wei li, Research on Living Protection and Tourism Utilisation of Intangible Cultural Heritage: A Case Study of Dehua Porcelain Production Technique). Fujian shida Fuqing fenxiao xuebao (福建師大福清分校學報) 6(133): 10-4.

FRANCIONI, Francesco. 2012. "Public and Private in the International Protection of Global Cultural Coods." European Journal of International Law 23(3): 719-30.

GAO, Binzhong. 2013. "How Does Superstition Become Intangible Cultural Heritage in Postsocialist China?" Positions: East Asia Cultures Critique 22(3): 551-72.

GONG, Zehui. 2017. "The Artistic Style and Application Research of Macheng Folk Paper-cut." Advances in Social Science, Education and Humanities Research 124: 444-8.

KEANE, Michael. 2013. Creative Industries in China: Art, Design and Media. Cambridge: Polity.

KIRSHENBLATT-GIMBLETT, Barbara. 1995. "Theorising Heritage." Ethnomusicology 39: 367-80.

KREPS, Christina. 2012. "Intangible Threads: Curating the Living Heritage of Dayak Ikat Weaving." In Michelle L. STEFANO, Peter DAVIS, and Gerard CORSANE (eds.), Safeguarding Intangible Cultural Heritage. Woodbridge: Boydell Press.

LI, Jian, and Xiaohan NIU. 2003. "The New Middle Class(es) in Peking: A Case Study." China Perspectives 45: 4-20.

LI, Jie 李傑, DENG Wanwen 鄧琬雯, and HUANG Guobin 黃國彬。 2019. “樺樹皮製作工藝保護傳承的可行性分析” (Huashu pi zhizuo gongyi baohu chuancheng de kexingxing fenxi, Feasibility Analysis of the Protection Inheritance of Birch Bark Production Process). Chanye jingji (產業經濟) 9(303): 57-9.

LI, Xiuyuan 李修遠, and MA Zhiyao 馬知遙. 2020. “傳統工㙯類非物 質文化遺產的市場化保護” (Chuantong gongyilei feiwuzhi wenhua yichan de shichanghua baohu, Research on the Market Protection of Intangible Cultural Heritage in Traditional Craft). Chengdu daxue xuebao (shehui kexue ban) (成都大學學報 (社會科學版)) 192 (6): 28-35.

LIANG, Yongjia. 2013. "Turning Gwer Sa La Festival into Intangible Cultural Heritage: State Subscription of Popular Religion in Southwest China." China: An International Journal 11(2): 58-75.

LINCOT, Emmanuel, and Michael BLACK. 2004. "Contemporary Chinese Art Under Deng Xiaoping." China Perspectives 53: 67-72.
LUO, Yi. 2021. "Safeguarding Intangible Heritage through Edutainment in China's Creative Urban Environments." International Journal of Heritage Studies. (accessed on 15 July 2021).

MAAGS, Christina. 2018a. "Creating a Race to the Top: Hierarchies and Competition within the Chinese ICH Transmitters System." In Christina MAAGS, and Marina SVENSSON (eds.), Chinese Cultural Heritage in the Making: Experiences, Negotiations and Contestations. Amsterdam: Amsterdam University Press.

. 2018b. "Disseminating the Policy Narrative of 'Heritage under Threat' in China." International Journal of Cultural Policy 26(3): 273-90.

2019. "Struggles of Recognition: Adverse Effects of China's Living Human Treasures Program." International Journal of Heritage Studies 25(8): 780-95.

MAAGS, Christina, and Heike HOLBIG. 2016. "Replicating Elitedominance in Intangible Cultural Heritage Safeguarding: The Role of Local Government-Scholar Networks in China." International Journal of Cultural Property 23: 71-97.

MASSING, Katharina. 2018. "Safeguarding Intangible Cultural Heritage in an Ethnic Theme Park Setting - The Case of Binglanggu in Hainan Province, China." International Journal of Heritage Studies 24(1): 66-82.

Ministry of Culture 中華人民共和國文化部. 2007. “文化部辦公廳 關於印發中國非物質文化遺產標識管理辦法的通知” (Wenhuabu bangongting guanyu yinfa Zhongguo feiwuzhi wenhua yichan biaozhi guanli banfa de tongzhi, Notice of the General Office of the Ministry of Culture on the Measures to Manage the Logo of China's Intangible Cultural Heritage). http://zwgk.mct.gov.cn/auto255/200803/ t20080305_465700.html (accessed on 11 July 2020).

Ministry of Culture and Tourism 中華人民共和國文化和旅游部、 2018. “文化部辦公廳教育部辦公廳關於實施2017年度中國非 物質文化遺產傳承人群研修研習培訓計劃的通知” (Wenhuabu bangongting jiaoyubu bangongting guanyu shishi 2017 niandu Zhongguo feiwuzhi wenhua yichan chuancheng renqun yanxiu yanxi peixun jihua de tongzhi, Notice of the General Office of the Ministry of Culture and the General Office of the Ministry of Education on the Implementation of the 2017 Plan on Researching and Studying the Training of National ICH Inheritors). https://www.mct.gov.cn/whzx/ ggtz/201701/t20170118_695645.htm (accessed on 11 July 2020).

.2008. “國家級非物質文化遺產項目代表性傳承人認 定與管理暫行辦法” (Guojia ji feiwuzhi wenhua yichan xiangmu daibiaoxing chuancheng ren rending yu guanli zanxing banfa, Interim Measures for the Recognition and Administration of Nationallevel Representative ICH Inheritors). http://www.gov.cn/zhengce/ zhengceku/2019-12/25/content_5463959.htm (accessed on 11 July 2020).

. 2012. “文化部關於加強非物質文化遺產生產性保護的 指導意見” (Wenhuabu guanyu jiaqiang feiwuzhi wenhua yichan shengchanxing baohu de zhidao yijian, Guiding Opinions of the Ministry of Culture on Strengthening the Productive Protection of Intangible Cultural Heritage). PKU Law Database. www.pkulaw.cn (accessed on 11 July 2020). 
State Council 國務院. 2005. “國務院辦公廳關於加強我國非物 質文化遺產保護工作的意見” (Guowuyuan bangongting guanyu jiaqiang woguo feiwuzhi wenhua yichan baohu gongzuo de yijian, Opinions of the General Office of the State Council on Strengthening the Protective Work of China's Intangible Cultural Heritage). http:// www.gov.cn/gongbao/content/2005/content_63227.htm (accessed on 11 July 2020).

2018. "China's Ministry of Culture and Tourism Inaugurated in Beijing." http://english.www.gov.cn/state_council/ ministries/2018/04/08/content_281476105453512.htm (accessed on 11 July 2020).

SIGLEY, Gary. 2010. "Cultural Heritage Tourism and the Ancient Tea Horse Road of Southwest China." International Journal of China Studies 1(2): 531-44.

SVENSSON, Marina, and Christina MAAGS. 2018. "Mapping the Chinese Heritage Regime. Ruptures, Governmentality, and Agency." In Christina MAAGS, and Marina SVENSSON (eds.), Chinese Cultural Heritage in the Making: Experiences, Negotiations and Contestations. Amsterdam: Amsterdam University Press.

United Nations Educational, Scientific and Culture Organisation (UNESCO). 1972. "The World Heritage Convention." UNESCO. https://whc.unesco.org/en/convention/ (accessed on 23 May 2020).

2003. "Text of the Convention for the Safeguarding of the Intangible Cultural Heritage." UNESCO. https://ich.unesco.org/en/ convention (accessed on 23 May 2020).

2020a. "The States Parties to the Convention for the Safeguarding of the Intangible Cultural Heritage (2003)." UNESCO. https://ich.unesco.org/en/states-parties-00024 (accessed on 23 May 2020).

2020b. "Purpose of the Lists of Intangible Cultural Heritage and of the Register of Good Safeguarding Practices." UNESCO. https://ich.unesco.org/en/purpose-of-the-lists-00807 (accessed on 23 May 2020).
WALLEY, Keith, and Chen LI. 2013. "The Market for Luxury Brands in China: Insight based on a Study of Consumer's Perceptions in Beijing." Journal of Brand Management 22: 246-60.

WANG, Zaidong. 2018. "Exploration of Industrialization Road of Folk Dance Fanshanjiaozi", Advances in Social Science. Education and Humanities Research 266: 153-8.

WANG, Li. 2019. "Rights and Obligations of 'Transmitters' in the Commercialization of ICH." Paper presented at International Cultural Heritage: Reconceptualization, Uses and Marketization, International Workshop at Zhejiang University; Zhejiang, 18-19 May 2019.

World Intellectual Property Organisation (WIPO). 2020. "Intangible Cultural Heritage Law." https://wipolex.wipo.int/en/legislation/ details/8939 (accessed on 25 May 2020).

YAN, Hongliang, and Bill BRAMWELL. 2008. "Cultural Tourism, Ceremony and the State in China." Annals of Tourism Research 35(4): 969-89.

YOU, Ziying. 2020. "Conflicts over Local Beliefs: 'Feudal Superstitions' as Intangible Cultural Heritage in Contemporary China." Asian Ethnology 79(1): 137-59.

YU, Yufan 俞釷凡, YIN Kexin 尹可昕, and PENG Guifang 彭桂芳。 2020. “奢侈'品視角下'非遺'類藝術品的生成與市場化運作研 究" ("Shechi" pin shijiao xia "feiyi" lei yishupin de shengcheng yu shichanghua yunzuo yanjiu, Study of Intangible Cultural Heritage Cultural Products Marketing Strategy Based on the Perspective of Luxury Goods). Wenhua ruanshili yanjiu (文化軟實力研究) 4(5): 4456.

ZHANG, Qiaoyun. 2020. "Intangible Cultural Heritage Safeguarding in Times of Crisis. A Case Study of the Chinese Ethnic Qiang's 'Cultural Reconstruction' after the 2008 Wenchuan Earthquake." Asian Ethnology 79(1): 91-113.

ZHU, Yujie, and Christina MAAGS. 2020. Heritage Politics in China: The Power of the Past. London: Routledge. 